\title{
Jeremy Fisher
}

\section{The Professional Author: Researching creativity and reality}

This paper was delivered on 25 November 2005 as a Plenary Address at Alchemy: Blending Research and Creativity, the Tenth Annual Conference of the Australian Association of Writing Programs, Curtin University of Technology, Perth, 25-27 November 2005.

\begin{abstract}
Writers expend considerable energy researching the details of time, place and character when developing their narratives. However, writers often neglect even most basic market research, to the detriment of publishing opportunities. When writing courses do not address fundamental issues related to writers making a living contracts, copyright, legal issues - and do not encourage writers to consider themselves as part of an industry that survives on market forces they do students of writing a disservice. Writers need to know not only how to research a novel or a biography but also how to prepare a publishing proposal, what returns they are likely to get for their labours and the contractual obligations they'll be under. They also need to know how to avoid defamation or breaches of copyright. Professional organizations such as the Australian Society of Authors (ASA) provide this support. The ASA also researches and publishes information on the publishing industry. It uses this information to lobby for government support for writers and to develop opportunities for writers to develop extra income streams. The ASA is also making its pictorial and sound archives, which feature many prominent authors of the past 50 years, available for research.
\end{abstract}

If politics is the art of the possible, research is surely the art of the soluble. Both are immensely practical-minded affairs.

- Peter B. Medawar

Research is usually a policeman stopping a novel from progressing. 
Research is formalized curiosity. It is poking and prying with a purpose. It is a seeking that he who wishes may know the cosmic secrets of the world and that they dwell therein.

- Zora Neale Hurston

As part of my research for An Anthology of Authors' Atrocity Stories About Publishers, I conducted a study (employing my usual controls) that showed the average shelf life of a trade book to be somewhere between milk and yoghurt.

- Calvin Trillin

Without an indigenous literature people can remain alien in their own soil. An unsung country does not fully exist or enjoy adequate international exchange of the inner life. Further, a country must be portrayed by those who hate it or love it as their dwelling place, familiarly, or remain dumb among its contemporaries.

- Miles Franklin

\section{Introduction}

Research is often as much a product of serendipidity as it is hard work, and sometimes one can lead to the other. I was reminded of this a year or more after I had published in Overland a small section of the exegesis accompanying the creative work that formed the bulk of my doctoral submission (note1). Out of the blue I received an email from UTS advising they had been contacted by a Leo van de Pas. Van de Pas asked whether they could pass on my contact details. I agreed. A few days later I was in conversation with Leo, and found he had lived in Perth with Gerry Glaskin from 1968, when he'd come out from the Netherlands, until 2000 when Gerry died. Actually, I had recognised Leo's name from the byline accompanying a photograph appearing with Carolyn van Langenberg's article on Gerry Glaskin in a previous issue of Overland (note 2).

However, I didn't realise the intimate connection between the two men. It was only after I met Leo that I came to know about their long life together.

Just as serendipitously, when I started my job at the Australian Society of Authors (ASA) I discovered Gerry's old membership file sitting high up on a dusty shelf in my office. Why it was there and not in the archives I have no idea. I can't tell you what was in it in any detail, but it reveals Gerry's obsessions and enthusiasms in often cantankerous, but always elegant, correspondence with my predecessors and his publishers.

Gerry's work, as Carolyn van Langenberg notes in her article, has been forgotten by and large. Carolyn mentioned that she had never read his book No end to the way. It was this brief sentence that that spurred me to submit my article, as I had not only read the book, I'd devoted a large section of my exegesis to documenting its place as one of the first overt gay narratives in Australia. This was an opening for my research. No end to the way is set in Perth. It's a terrific book, one deserving of more attention, but unfortunately it is only odd researchers such as myself who deem it worthy of a more significant audience.

Another serendipitous aspect to all this was that Leo liked what I had written. As a consequence, I met him in Canberra where he now lives, and we had a great chat about Gerry and his writing and the lives these two men had led together. In my writing life, as opposed to my life as an author's advocate, I am researching and writing about the lives of men who 
live together. There's not much written about that because it is only comparatively recently that it was a topic able to be written about. The research often involves conversations with elliptical meanings, and a filling in the gaps with knowledge acquired elsewhere. Then fascinating glimpses, such as the one Leo discovered in one of Gerry's books; a 1958 letter to Gerry from Yukio Mishima, extolling the sexual allure of adolescent boys.

But I am already running down the byways, back alleys and cul de sacs to which research often leads. What I intend is set out what a writer needs to do in terms of research if he or she is to set out on a career as a writer. By that, I mean that a writer who seeks to live largely on the income generated by his or her writing. This involves both art and craft. I am concerned that writers focus more on the art and less on the craft. In this, they are perhaps falling victim to a perceptual problem facing all artists in Australia. I was reminded of this recently when in conversation with Peter Garrett, now Shadow spokesman for Reconciliation and the Arts and formerly, for 27 years, the lead singer and contributing songwriter to the rock and roll band Midnight Oil. Peter was espousing his undoubted support for the arts. He said: 'But I'm just a songwriter and musician, I'm not an artist.' I begged to differ. I said I regarded him and his colleagues in the band as artists. Peter replied saying that, while he was gratified I thought he was an artist, he felt unqualified as the band had never received a grant to help them get ahead. The first five years were a struggle to earn enough to survive and continue making music and after that, with some commercial success, Peter felt more that he was operating a small business than being an artist.

It worries me that we have this dichotomy where someone who is so obviously an artist, and who is now in a position to influence debate about cultural policy, doesn't feel he is an artist because he has been too commercially successful. It worries me that as a culture we don't equate artistic success with commercial success, that we put art on some elite pedestal. It worries me that we have a perception of art that is not based on how well it engages with its intended audience but only how well it engages with a few like minds, and it worries me that it is so distanced from the culture from which it purportedly emanates.

I want our writers to be like Peter Garrett, to feel that they are small businesses. There are certain assumptions involved in that. One is that writers aim to live from the proceeds of their art and craft; another is that there is a market able to sustain them in their work; another is that a business need not necessarily be for profit, but to survive it does need to take note of the environment about it, needs appropriate practices in place to ensure its ongoing viability, and needs to engage with its market. All of this, and the research underlying it, is what we are failing to offer our new and emerging writers, or even those who have had some success.

Tom Keneally writes about researching subject matter in the latest issue of the Australian Author. He says he favours newspapers for novels not because they are 'sources of indomitable truth but [because] you get from them a peculiar kind of unintended truth - basically a picture of the era' (note 3). But Keneally also uses libraries and other archives for research to ensure his historical information is accurate. He acknowledges that this is hard work, and requires meticulous attention to detail. This is all part of the craft of writing. But Keneally is also aware that a writer needs to do more than simply research his or her stories. The first sensible thing a writer ought to consider is what sort of life he or she can look forward to as a writer. A life of luxury is highly unlikely. Even the successful 
Keneally enjoys only temporary affluence as a result of a film or a bestseller. But I wonder how many starry-eyed students of creative writing think that, magically, they will become a new Bryce Courtenay or J.K. Rowling. It is my contention that they need to research the reality of writing if they are fully to understand the profession they seek to enter.

\section{Writers' Incomes}

Reality starts with money. No money, no life. It is a truth universally acknowledged that publishers are the main beneficiaries from writing, and receive the greatest financial benefits from an author's work. I'm not out to bag publishers for this. It is not as if they're bankers. If they were, they could be earning even more than they do.

Up until 2002-03, the returns from publishing in Australia were not significantly different from returns from cash investment. Between 200102 and 2002-03, the operating profit before tax for book publishing businesses in Australia increased from $\$ 50.2$ million to $\$ 88.4$ million. The profit margin increased from $3.3 \%$ in $2001-02$ to $5.6 \%$ in $2002-03$. These are not enormous sums in the grand scheme of things. The operating budget for the Australia Council, for example, is around \$130 million. BHP Billiton delivered a profit of about $\$ 5$ billion.

In 2003-04, however, this situation changed dramatically. Overall operating profit for that period was $\$ 152.1$ million or $9.7 \%$. The profit margin for the 20 largest book publishers was $4.4 \%$ in $2002-03$ but rose to $9.7 \%$ in $2003-04$. Other book publishers had a profit margin of $10.2 \%$ in 2002-03 and $12.7 \%$ in 2003-04, which is a very healthy return by any standard.

There are other ways for publishers to make money: the Copyright Agency Limited (CAL), for instance, paid out $\$ 43,206,192$ to 3292 publishers in 2004-05. This represents an average payment per publisher of $\$ 13,125$; but the largest CAL payments tend to go to the largest educational publishers. Publishers add CAL income not distributed to authors to their bottom line, thus increasing profitability. Publishers also receive Public Lending Right (PLR) and Educational Lending Right (ELR) money. In 2003-04, 328 publishers received PLR money; 14 received PLR payments in excess of $\$ 20,000$, and two received payments greater than $\$ 100,000$.

Profits of course go to the owners. But the people employed in publishing don't do too badly. At the end of June 2004, there were 5,300 people employed in book publishing in Australia. In 2003-04, 3,547 (67\%) of these 5,300 employees were employed by the 20 largest publishers. In 2003-04, wages and salaries paid by publishers came to $\$ 266.1$ million, which represented $19 \%$ of publishers' total expenses. In 2002-03, the average salary of full-time publishing employees was $\$ 46,554$. In 2003-04, this had risen $\$ 52,300$, an increase of $9 \%$ over the previous year. However, only 3972 of these employees were full-time. Therefore, many people working in the publishing industry earn much more. Senior sales and publishing managers may well receive $\$ 150,000$ to $\$ 200,000$, or even more with bonus payments and fringe benefits. Sales representatives will have salaries from $\$ 50,000$. Administrative staff members have salaries starting from $\$ 40,000$ (note 4). As I said, it is a truth universally acknowledged that publishers are the main beneficiaries from writing. My paraphrase dispenses with Jane Austen's irony. 
What about editors? Publishers use the term 'editor' with some looseness. 'Acquisitions' or 'Commissioning' editors may be publishers, and receive payment as such. The term 'editor' as used in this paper refers to people who work on a manuscript and shepherd it through the production process. and are covered under the Book Industry Award. Under this award, trainee editors commence on a salary of $\$ 30,600$, and the highest grade receives nearly $\$ 51,000$ plus $9 \%$ superannuation. In practice, many publishers pay above these rates and offer fringe benefits. The freelance rate for book editors currently appears to vary between $\$ 45$ and $\$ 75$ per hour. How many freelancers can be assured of this rate, however, depends on their desperation and the publisher's powers of persuasion.

Indexers too demand a base rate for payment. The Australian and New Zealand Society of Indexers (ANZSI) recommends a base rate of $\$ 55.00$ (excluding GST) an hour for its members.

And then we have the authors. Authors must earn more than editors and indexers, right? After all, they have so many possible income streams. They can make a living from royalties, payments for subsidiary rights, lending rights payments and payments for statutory reprographic rights (administered by CAL).

Despite this, authors remain at the bottom of the chain when it comes to remuneration from publishing. The Throsby and Hollister report Don't give up your day job (2003) prepared for the Australia Council indicates that in the period 2000-01 writers had a mean arts income of $\$ 26,400$ and a median arts income of $\$ 11,700$ (note 5). This means that authors cannot live from writing alone, although publishers and editors can live quite well on the income generated by the work of authors.

So what did authors receive? In 2001-02, out of sales of Australian titles of $\$ 853.8$ million, creators were paid royalties and fees of $\$ 93.06$ million, or $10.9 \%$. In 2002-03, out of sales of Australian titles of $\$ 877$ million, creators were paid royalties and fees of $\$ 102.6$ million, or $11.7 \%$. This amount dropped in 2003-04 to $\$ 90.9$ million: that is, $6.5 \%$ of sales.

In 2004-05, payments from CAL to publishers and authors totalled $\$ 48,123,313$, of which only $10.2 \%(\$ 4,917,121)$ was paid directly to 3906 authors (note 6), an average payment of $\$ 1259$. It is unknown how much of the amount paid to publishers $(\$ 32,718,774)$ was on-paid to authors for whom the publisher collected; but publishers collected an average of $\$ 13,125$. Even if they paid half of this to authors, publishers were still better off than the average author. Despite the fact that CAL was founded as an initiative of members of the ASA working with publishers, there is evidence from ASA members that a number of large educational publishers with older contracts - that is, with no clause covering collection of or sharing CAL payments - are collecting for authors when they have no licence to do so, and are retaining funds to which they have no legal entitlement.

The only area where authors do better than publishers in terms of payments is lending rights, which were implemented following action from the Australian Society of Authors. The PLR Committee recommended an increase in the PLR payment rate in line with the annual increase in the funding allocation for the scheme in 2003-04 (note 7). The rate per copy of each eligible book was $\$ 1.37$ for creators and 34.25 cents for publishers, compared with $\$ 1.34$ and 33.5 cents in 2002-03. The 
Committee approved annual payments of \$6 501793.18 for 2003-04, distributed to 8737 claimants of whom 8409 were creators (3869 females and 4540 males)and 328 were publishers. The majority of creators received payments of less than $\$ 3,000$. Seventeen creators received payments greater than $\$ 20,000$.

Payments for Educational Lending Rights have not increased in the same manner as PLR, as funding is fixed. ELR payments commenced in 2000 as part of the Book Industry Assistance Plan initiated in response to the imposition of GST on books. Funding for ELR commenced in 2000-01 at $\$ 8$ million, and increased to $\$ 11$ million in the final year, 2003-04. An extension of funding of $\$ 44$ million over four years from 2004-05, up to 2008, was provided in the 2004-05 Federal Budget. For the period 200304 , ELR payments totaled $\$ 10.23$ million, made to 8285 claimants of whom 7981 were creators (3848 females and 4133 males)and 304 were publishers whose books are held in educational libraries (school, TAFE and university libraries).

Life as a writer is clearly unrewarding in the current climate, even for books that have an elevated status. This is despite the fact that, as Gillian Armstrong indicated in her speech at the 2005 Miles Franklin Award, from the first winner, Patrick White's Voss in 1957, to the present, the winners have provided a rich vein of stories for our film-makers and also for television. But while films such as Armstrong's My Brilliant Career and Oscar and Lucinda have their genesis in strong Australian works of fiction, and an original film-script such as that for Ray Lawrence's Lantana owes much to the imagery of Eleanor Dark's Lantana Lane, the authors of those books rarely benefit in financial terms from the exploitation of their works in this context.

At present, even those making films in Australia find it difficult to break even. This is a world-wide phenomenon. Currently, attendance at cinemas in the US is in the third year of decline (note 8). Ticket sales in 2005 were $10 \%$ below 2004 levels. Similar declines have been anecdotally reported recently in Australia but are not revealed in the numbers. The total 2004 Australian box office was $\$ 907,218,000$, a result $\$ 41$ million $(4.79 \%)$ better than 2003 .

Australian films earned a combined total of $\$ 11,878,014$ in 2004 , or only $1.3 \%$ of box office. Strange Bedfellows topped the list of Australian films, taking \$4.8 million, and Somersault, by first-time director Cate Shortland, took $\$ 2$ million. These two movies earned more than $50 \%$ of the box office for Australian films. A total of 318 films were released into the Australian theatrical market in 2004, of which only 16 were Australian films (12 features and four documentaries), compared to 22 feature films and one documentary in 2003 (note 9). US films dominated the Australian box office, with 200 US titles (or 63\% of films released) released in 2004 . US films took $85.9 \%$ of the total box office in 2004 , up from $83.8 \%$ in 2003. This is a depressing trend for the Australian film industry. It is also reflected in television. Australian content on Australian television amounts to only $24 \%$ of the total content broadcast. In contrast, $96 \%$ of the content broadcast on US television is produced in that country and $91 \%$ of the content broadcast on British television is produced in the UK. Canada, which shares many of the same issues as Australia in being a 'second fiddle' in the global English market, manages to broadcast $75 \%$ of Canadian content on its television services (note 10). 
It is interesting in this context that sales of books in Australia have been increased. What has been noticeable however is the large numbers of copies sold of a few titles. In 2003-04, for example, 128.8 million books were sold, an increase of 14.4 million over 2002-03. Sales were dominated by over 900,000 copies of Harry Potter and the Order of the Phoenix and 1,777,000 copies of four Dan Brown books. After these titles, the next best-selling book in their categories sold 65,000 copies. Book buyers, it seems, were looking for homogeneity. Why this might be so raises many questions.

Unlike the state of the film industry, sales of Australian music repertoire increased in 2004. Sales of Australian titles in the ARIA Top 100 Albums Chart increased $32 \%$ by volume, up from $28 \%$ in 2003 . Anecdotally, it appears these sales are for independent artists, rather than for those owned and produced by the major labels, which suggests that music buyers, unlike book buyers, are rejecting mass marketing strategies. But sales of recorded music over all are declining. The decline in both the volume and value of the recorded music market has been attributed to various factors. One is the continuing effect of products such as digital music carriers (iPods) and advanced mobile telephones. It has also been argued that the significant growth in the uptake of high speed (broadband) internet access in Australia in 2003-04 has made the illegal downloading of music easier. In 2004, the sales of ringtones for phones in the UK market were double those for singles at $£ 120$ million (A $\$ 278$ million) (note 11). One particular ringtone, Jamster's 'Crazy Frog', morphed into a best-selling single ('Axel $\left.F^{\prime}\right)$.

A further factor in the decline of the recorded music market is the growth of the non-music DVD market. Non-music DVDs, which might be seen as logical competitors to books (as videocassettes were when they were first introduced as a leisure purchase), are often being sold through the same retailers who offer recorded music, and recorded music has lost shelf space to non-music DVDs (note 12). DVD players and DVDs have become major consumer purchases. In 2003, 1.5 million DVD players were sold in Australia, up from 170,000 in 2000. As well, there has been a huge swing from conventional VHS tape towards DVDs. The Australian Visual Software Distributors Association has noted that DVD rentals, at 17 million, passed those for videotapes in 2001-02. They increased $75 \%$, to 28 million in the year to July 2003 (note 13).

In line with these scenarios, there have been a number of suggestions that fiction, dependent as it is on reading as a leisure activity, is suffering a similar downturn. Journalist and novelist Malcolm Knox has analysed how publishers use information on sales as provided by Bookscan to make publishing decisions (note 14). Bookscan measures sales of trade titles (no educational titles are measured) across a wide range of suppliers, and aggregates the results by collecting transactional data at the point of sale directly from the tills and despatch systems of all the major book retailers. In a week Bookscan can collect data on over 60,000 titles (note 15). It offers homogeneous data, without necessarily considering what might be selling well in inner-city Sydney or rural Western Australia. Knox argues that homogeneous data leads to homogeneous publishing decisions. If these decisions lead to million copy-selling books, publishers (and authors) can be pleased. But the downside of this sort of analysis is that more books may be published that fail to meet unreal expectations because they are not marketed to their potential smaller audiences but rather to an unreceptive, homogeneous whole. Also, while comprehensive, Bookscan fails to pick up any sales trace of books that might be akin to independent 
music. Self-published book sold over the internet, books that sell well in one region through non-traditional sources and other books are ignored. Yet this market could be quite sizable, as suggested by data from the US publishing industry.

Nevertheless, there is anecdotal evidence from agents, writers and publishers that only books that will sell above a relatively high baseline will be offered a contract. Certainly, the ASA has been advised by one major Australian publisher of fiction (Hodder Headline, now Hachette Livre Australia) that 'zeroes' (representing the thousands of copies sold) are what count most in deciding whether or not to publish a book, and that the number of fiction titles being published had been reduced as a result of publishing decisions based on this analysis (note 16). This is an understandable position from publishers working for profit. But most 'for profit' businesses spend some money on research and development to extend markets and market share. Publishers on the whole do not appear to be doing that with regard to developing new authors.

Part of this relates to the conservatism of the industry. In publishing, profits come from sales; one book selling a great hundreds of thousands of copies makes more than several books selling the same number of copies since it presents a greater return on investment (ROI) for the publisher. This of course is also beneficial to the author whose book sells many thousands of copies, and the pursuit of this goal is the primary reason for the contractual knot into which authors and publishers tie themselves. But, as a consequence of this, marketing and sales representatives tend to stick with the tried and true. Most publishers offer their sales representatives some form of bonus for increased sales. Even though it is more difficult for a sales representative to persuade a bookseller to take 50 copies of a new, unknown Australian author than 50 copies of a well-known, highly publicised Dan Brown or J.K. Rowling title, most publishers provide no incentive for representatives to make the extra effort for the new book. Not unnaturally, sales representatives pursue the easiest option to earn their bonuses, so the myth that the market is not interested in new Australian writers is perpetuated in sales patterns and results.

It would be erroneous to infer from this that publishers do not promote new authors. They do, but the task of publicising and marketing a new unknown author is daunting when this requires interaction with the elements of the mass media that are more interested in known celebrities, paid endorsement or contra deals. As a result, the cost of establishing a media presence for an author, and thus some mass-market credibility, involves payments for interviews and appearances, gratuities and gifts. It may be many thousands of dollars. This sort of expenditure is not viable for a publisher anticipating a moderate return on a new novel or scholarly biography. It's a cost of which the average author is able only to dream. Hence, authors' reputations have tended to develop incrementally, through word of mouth, the winning of literary prizes, favourable reviews, appearances at writers' festivals and appearances in non-commercial or fringe media. Literary agent Jenny Darling referred to this as 'the amnesia in the industry that most authors are not an overnight success' (note 17). The creation of a recognised author is a slow process that does not fit well with publishers' desires for immediate profits. A 'writer' with an immediately recognisable profile - a sports star, perhaps, or an errant politician, or a television star - is a safer option in guaranteeing sales.

Recently, there has been some attention given to the differences between 'popular' and 'literary' writers (note 18), with agent Selwa Anthony 
promoting her stable of 'popular' writers as writers who sell, compared with the boring 'literary' writers who might feature at the Sydney Writers' Festival. While any publicity for writers and their works is arguably useful in encouraging sales, surely sales of any sort of Australian book are good for Australian writers. We do risk making ourselves artistic 'freaks' if we do not engage with our markets, but there are more markets than the mass market. Writers need to know their own particular market well.

Suggestions that 'literary' writers are writers whose works do not sell may be beneficial for an agent's profile, but they are one-sided. Markets can be fickle. The nineties were rewarding for writers of literary fiction; the 'noughties' are not. Why this is so is already the subject of much interesting research, but there is no place there for the disparagement of the works themselves. Nor should the current popular works be disparaged because they do not meet some artistic pretensions. If they are good stories and readers are reading them they have been judged a success in their marketplace. However, we are reaching a point where the existence of a healthy variety of Australian narratives can no longer be taken for granted.

In this regard, the ASA recently took issue with the manner in which Books Alive, an Australian Government initiative begun in 2000 as part of the GST compensation package provided as assistance for the book industry, was promoting Australian authors. By 2005, a campaign that had begun with a number of Australian books from different genres being offered as lower-priced purchases along with that of another full-priced book had mutated into a Great Reads Guide that featured 50\% nonAustralian titles. All the titles featured in the 2005 Guide were also books that had sold well and did not really need extra promotion. Again, the Guide could be interpreted as a move towards homogenisation and the provision of more of the same type of books. It offered little support for struggling Australian writers. In the current climate, homogeneity in publishing decisions is a safer course of action for publishers rather than promoting new, untried voices. Homogeneity has not yet translated into lower revenues for publishers. In fact, there is evidence it is having an opposite effect.

\section{The Global Context}

As an industry, publishing is inherently conservative, and this is the case worldwide. I'd now like to look at the global context of publishing now as a means of introducing the structure of the industry in Australia.

Most publishing decisions are reactive, rather than proactive. As businesses driven by the need to make profits for shareholders or partners, publishers as a matter of course seek to attain the greatest return on their investment. In doing so they are well advised to be cautious and to ensure they have appropriate risk management strategies in place. In practice, however, this conservatism often translates into 'follow the leader'. Publishers are always chasing the last successful book, rather than looking for something new to challenge and entertain readers. As indicated earlier, sales and marketing strategies encourage this, even when editorial attitudes might veer towards recognisably different works. Hence, with the Dan Brown's The Da Vinci Code having sold over 1 million copies in Australia in 2004-05, we can expect to see a range of books attempting to emulate that success, much as books similar to J.K. Rowling's 'Harry Potter' series emerged after its success, even though there were many interesting variations already available in a flourishing fantasy genre. 
Publishers take whatever information they can gain from their limited market research to attempt to minimise their risk and exposure and guarantee sales. Even so, this research is essentially reactive as it follows from publishing decisions already made. Even so, the sales of Dan Brown and J.K. Rowling still come as a surprise; their extreme success was not envisaged by their publishers. Rowling in particular had her manuscripts rejected time and again before being successfully published. Jenny Darling makes the point that Dan Brown was not an overnight success either (note 19). In the big English-speaking markets the US and the UK, there is considerable research undertaken with regard to publishing patterns and book-buying. Research in Australia is relatively scant, meaning it is necessary to extrapolate data from overseas into the Australian marketplace. This process does not always offer much coherency. Nevertheless, I offer the following insights from these markets.

\section{The United States Market}

US data indicate that US publishers put out 14\% more titles in 2004 (a total of 175,000) than they did in 2003 (note 20). Approximately 50,000 of the total number of titles were produced by vanity and print-on-demand (POD) publishers while the other 125,000 came from a combination of minor and major industry players. The 12 major houses output, a total of 24,159 new titles, was an increase of $5.4 \%$ on the number produced in 2003. Output from university presses was also up $12.3 \%$ to a 2004 total of 14,484 titles. These figure show that a vast number of titles was coming from sources other than the 12 major publishing houses. A report by the US Book Industry Study Group (BISG), Under the Radar, indicates that in the US approximately 63,000 publishers with annual revenues of less than $\$ 50$ million produce aggregate sales of US\$14.2 billion (note 21). The sales of these publishers had gone unreported previously. About US $\$ 11.5$ billion of that amount comes from around 3,600 of those publishers with annual revenues of US\$1 million to US\$49.9 million. In contrast, the older, more visible segment of the industry produces annual revenues of around US\$25 billion. The BISG reports that the number of small and midsize publishers has been increasing, and often prospering, while the largest publishing companies have been consolidating. These smaller publishers have been using routes to readers outside traditional bookshops. They are often selling more books outside trade channels than within them, with more than $50 \%$ of their business outside book-trade channels. There is no analysis of similar developments in the Australian industry.

Further, US data show that adult fiction output increased $43.1 \%$ from 2003, accounting for 25,184 new titles. However, the larger publishing houses, while experiencing $3.5 \%$ growth in this area, were not primarily responsible for the increase in the number of adult fiction titles. The US data also show that adult non-fiction titles increased in the religion, travel and home economics segments (the terms are those used in the US), although the output of religious titles from the majors declined. Poetry increased, mainly published through vanity and POD publishers. Young Adult titles were up $6.6 \%$ to 21,516 in 2004 .

The value of sales in the US in 2004 also increased, albeit marginally. In February 2005 the Association of American Publishers (AAP) reported a minimal increase in the value of net sales of $1.3 \%$ from 2003 to 2004 to \$US23.72 billion (note 22). The value of trade sales rose 1.9 per cent, with sales of $\$$ US5.16 billion. The adult trade hardback segment was up 6.3\% 
(\$US2.61 billion), while paperback sales increased 2.8\% (\$US1.51 billion). Despite the increased number of books published in the segment, Young Adult (YA) hardback sales were down 16.7\% (\$US581 million), though YA paperback sales were up 3.8\% (\$US465.6 million). In the educational area, the value of school sales, increasing only $0.1 \%$ (\$US4.30 billion), and higher education sales, increasing only 1.8\% (\$US3.45 billion), were flat. The value of the sales of professional and scholarly books was up 2.0\% (\$US4.06 billion). The value of book club and mail order sales (\$US1.18 billion) and mass-market paperback sales ( $\$ 1.11$ billion) both decreased 8.9 percent, continuing a decline first seen in 2003 . Sales of religious books (a category that includes many self help texts) grew 5.6\% in 2004 (\$US1.33 billion). 'Other' book publishing sales increased 5.0\% (\$US2.20 billion). However, the number of books sold in the United States in 2004 declined by nearly 44 million from 2.339 billion in 2003 to 2.295 billion. Interestingly, while the AAP reported that the prices of trade books remained much the same in the US, decreasing or increasing by only a few cents in different categories, it was higher prices for educational books which increased the value of sales, but also caused one of the biggest drop in sales numbers - that for university textbooks (note 23). Anecdotal evidence suggests that students are buying used editions of textbooks rather than paying the high price placed on the new books. University textbooks are also the highest-priced segment of the Australian book market. The BISG expects that this segment of the US market will steadily drop in terms of the numbers of books sold, suggesting the 68 million sold in 2004 will fall to 64.4 million in 2009. A similar trend may be expected in Australia where sales in the higher education market segment appear stagnant.

Leisure activity in the United States shows a big shift towards home video, DVD, internet and cable. As a result, attendance at cinemas has declined by up to $10 \%$ from 2004 to 2005 . In this context, book sales show surprising resilience, given the facts that Amazon now offers second-hand books for sale and there are so many other options competing for the attention of book-buyers. In the light of all this conflicting information, the BISG anticipates that 2005 will be a much better year in terms of the number of books sold as a result of the release of the new Harry Potter book and the fact that a number of US states are due to order new editions of school textbooks (this state decision-making is a key element governing educational publishing for schools in the US).

\section{The United Kingdom Market}

In the United Kingdom, the situation is not significantly different, although there has been a decline in the value of sales: $£ 3,188.6$ million in $2001 ; £ 3,154.8$ million in 2002; and $£ 3,053.5$ million in 2003. However, the number of new and revised titles published in 2004 was estimated to have increased to 160,000 from 130,000 in 2003 (note 24). The number of books sold increased to a total of 282 million copies in 2003 compared with 273 million copies sold in 2002. Fiction was the largest segment, with around 11,000 titles published in 2002, but there was a sharp variation between 2000 (about 9,500 fiction titles) and 2001 (nearly 13,000 fiction titles). Of 2,275 publishing businesses registered for VAT (the UK equivalent of GST) in the UK, only 90 had a turnover greater than $£ 5,000,000$ in 2002-03. Most UK publishers are relatively small businesses, and the same may also be said of the US and Australian 
markets. However, in each market the largest market share is held by a relatively few major players.

\section{The Australian Book Market}

How does the Australian book industry compare with the largest English language markets? What research there is on the Australian book industry has been conducted comparatively recently. Since 2000, the Australian Bureau of Statistics (ABS) has assessed the industry as part of the Book Industry Assistance Package given by the current Federal Government as compensation for the imposition of the GST on books. Data in this section comes from the ABS (note 25). The net sales value of the book market in Australia was worth $\$ 1,560.6$ million in 2003-04, a slight decline from $\$ 1,578.6$ million in 2002-03. In 2003-04, there were 234 businesses identified as book publishers and a further 10 identified as major contributors. Publishers and other major contributors based in New South Wales or Victoria accounted for $94 \%$ of total book sales $(51 \%$ NSW; $43 \%$ in Victoria).

In 2002-03, the overall operating profit (income, less expenses of $\$ 1,487.7$ million and a reduction in inventories of $\$ 2.5$ million) for the industry was \$88.4 million (5.6\%), but even with a decrease in net sales value 2003-04 proved a better year than the previous one with the overall operating profit rising to $\$ 152.1$ million $(9.7 \%)$ as expenses were lower at $\$ 1,404.4$ million and reduction in inventories was \$4.2 million. In 2003-04, 133 of 244 publishers were involved mainly in publishing books of general content while 111 were involved mainly with publishing educational books (including professional and reference books). While the entire Australian publishing market, including education, was worth A \$1,560.6 million in 2003-04, the US publishing market in 2004 was worth US\$24 billion and the UK market was worth about A $\$ 7$ billion. In global terms, the Australian market pales into insignificance, and the only reasons that any of the multinationals publishing in Australia dabble in Australian content are because there is a definite market demand and a degree of profitability. Just on $60 \%$ of the books sold in Australia originate in Australia, accounting for sales in 2003-04 of \$811.9 million. This is a vast change from 1960, when 75\% of the books sold in Australia were imported, and 1980, when $63 \%$ of the books sold in Australia were imported (note 26). However, the change in ownership of publishers has been insidiously the other way. Very few Australian companies feature on the list of the Top 20 publishers. However, it is interesting to note that the structure of the industry hasn't changed much in over 20 years. In 1982, there were 200 active publishers in Australia, compared with 234 in 2003-04. In 1982, no publishers had a turnover of more than $\$ 40$ million, and only $20 \%$ had a turnover of more than $\$ 2$ million. The majority had a turnover of less than $\$ 1$ million. This pattern was pretty much unaltered in 2003-04. While there are no publicly available figures on the turnover of most Australian publishing companies, it is possible to gauge their size through their reported activities and the annual reports of their overseas owners. As well, the ABS has reported (the only year it has done so) that in 2000-01, the 20 largest book publishers in terms of income earned an average of $\$ 52$ million each, while the remaining book publishers earned an average of $\$ 2$ million. Overall the 228 businesses involved in book publishing in that year earned an average of $\$ 6$ million each. 
These facts need to be placed in a global context. For example, the international operations of Harcourt Education, which include Australia, had an operating profit of A $\$ 69.6$ million for the six months ended June 2004, the 2004 world-wide revenue for McGraw-Hill in 2004 was A \$3,050 million with an operating profit of $A \$ 432$ million, and the 2003 world-wide revenue for Random House (part of Bertelsmann) was A $\$ 2,940$ million. In other words, the Australian market is a very small part of global publishing, and the global activities of some of the larger publishers operating in Australia are larger than the entire Australian market. Closer examination of the Australian market reveals that 77\% (\$1,198.3 million) of the 2003-04 total income for publishers and other major contributors was generated by the 20 largest (in terms of income) book publishers. These 20 publishers were equally as significant in sales, selling 78\% (\$1,057.8 million) of the value of total book sales and $76 \%$ (97.7 million) of all books sold, but their profit margin was lower than that for the overall industry at $9.5 \%$ in $2003-04$ while it was $12.7 \%$ for the other publishers.

Pearson Australia is the largest publisher in Australia. It is a division of Pearson plc of the UK, and is made up of Penguin and Pearson Education. The Australian business has a turnover in Australia and New Zealand of about $\$ 250$ million (about $16 \%$ of the total market) and employs 500 people. In 2000, Pearson bought the Viacom educational publishing group (Prentice-Hall was the main imprint). This gave Pearson the largest share of the US educational market (about $30 \%$ ). There was an inquiry by the US Congress before the acquisition was approved. As a result of this acquisition, however, Pearson's share of the Australian educational market became much, much larger. How big has never been quantified, but probably $40 \%$. A significant slice of the rest is in the hands of Reed Elsevier. The fact that Australian schools' textbooks are now produced by companies that are not regulated by Australian authorities, do not report to the Australian Stock Exchange and who have gained their market share without a whimper from our elected officials has never been a topic for public discussion. Pearson also owns United Book Distributors and provides distribution for a number of independent Australian publishers such as Text, Fremantle Arts Centre Press, UQP, and Anne O'Donovan.

After Pearson, the others jockey for position in the top 20 that dominates sales and market share. The market is divided into specialist areas, however, and publishers generally choose to operate in only one market segment. Pearson and Macmillan are the exceptions, though other players might have a minor niche area and companies such as Lonely Planet and Murdoch Books have carved out their own significant niche. Being a specialist publisher can be a lucrative business option, but it can have its perils. Lonely Planet was hard-hit after the terrorist attacks in New York of September 2001 affected travel and tourism, to which it is highly leveraged. It had to shed staff and cut back on its publishing operations. Likewise, legal publishers such as LexisNexis, Thomson Legal and $\mathrm{CCH}$ have had to address technological impacts on their business models as online delivery has eroded the income streams from loose-leaf services and forced them to consider different sales, marketing and distribution philosophies.

The crucial information for writers is: what books sell in Australia? A writer needs to know who his or her competitors are and the potential size of the market before committing to an investment of time and labour in the creation of a manuscript. Australian data do not allow much elaboration on the subject areas being published. The ABS data is only broken down by 
fiction, children's, non-fiction and educational. Bookscan information is more specific, but only available to subscribers. The APA compiles a list of bestsellers each year in the categories of adult hardbacks; adult trade paperbacks; adult mass-market paperbacks; children's hardbacks; and children's paperbacks. Only sales at retail outlets at standard publisher discounts and where the author gets a full royalty are included (note 27). Books by Australian authors sell well. The APA survey in the year up to 30 March 2004 showed the adult hardback Brother Fish by Bryce Courtenay (Pearson/Penguin) sold more than 250,000 copies at an RRP of $\$ 49.95$, topping the adult trade paperback category. That's sales worth about $\$ 12.5$ million at recommended retail price. An author receiving royalties on that at the ASA minimum recommended rate of $10 \%$ of RRP would pocket around $\$ 1.25$ million. The Reef by Di Morrissey sold over 105,000 copies at an RRP of \$30, topping that category; and the mass market adult paperback Friends to the End by Bradley Trevor Grieve sold more 50,000 copies at a RRP of $\$ 14.95$, coming in at No. 11 in that category, well behind Dan Brown whose books filled the first four positions.

There are other market areas where writers are making money. Education is big business, but there is no comprehensive analysis of sales in the educational market even though, currently, the education sector represents the largest publishing segment. It was worth $\$ 547.8$ million in 2002-03, with $\$ 342.5$ million of that resulting from Australian published material, but had dropped to $\$ 526.1$ million in 2003-04. Of the 2003-04 sales, books produced in Australia were worth $\$ 343.4$ million or $65 \%$ of educational sales. Most of these were for school use, the largest proportion of imported titles being used in tertiary education, though the number of imported titles being used in schools is growing and is a worrying trend for both culture and income for educational writers. The decline in sales of educational books reflects international patterns and perhaps the influence of internet in education. Copyright Agency Ltd is reporting a greater rate of copying of material available on the internet. The market size for educational publishing increased year by year since 2000 but plummeted to $\$ 498.8$ million in 2003-04. There were 4615 new Australian educational titles published in 2002-03 and 4610 in 2003-04.

I've already said that publishers make the most out of publishing. But who are these publishers? Currently, statistics defining the publishing industry encompass book traditional publishers. However, there is more publishing taking place that is not caught in this statistical analysis. As an indication of this, CAL reports that it has a great many more Australian publisher members than does the APA. CAL's publisher members include, as well as traditional publishers, government departments and agencies, professional societies and associations, community organizations, charities, universities, clubs, companies and other types of organizations. These publishers may or may not publish for profit.

There is also the non-commercial sector of the traditional publishing that often struggles even to recover its costs. Sometimes this area has moved online as a means of saving costs. It embraces poetry, which is widely seen as being non-commercial. Print runs for poetry are frequently as low as 200-500 units, hardly enough to get a traditional publisher on the phone, let alone investing money. Unfortunately this paradigm is increasingly being embraced by traditional publishers for any books that have potential sales of less than 10,000. This affects most new fiction and anything outside a narrow mainstream. It is probably the major problem facing writers today, in terms of being published and making a living. It is being driven by a desire for most publishers to maximise profits. 
Then there is the intricate corporate superstructure of the whole communications industry that has an impact on publishing. Cross media ownership has not always been considered with regard to book publishing. Critics and analysts of cross-ownership of media have tended to concentrate on newspapers and radio and television broadcasting. Indeed, the book publishing industry in Australia has been the subject of very little scrutiny with regard to ownership at all. One of the concerns with regard to cross-media ownership is that one player may end up with undue control of one market. The usual suspects are News, CanWest, the Packer companies and Fairfax. However, it must be remembered that Pearson is one of the world's largest media companies, owning newspapers and book publishers and having other interests in financial markets. As mentioned earlier, Pearson/Penguin makes up about $16 \%$ of the Australian book industry. Pearson used to have big television interests, even buying the Australian Grundy television production company, but it has eased out of this market. McGraw-Hill owns a wide range of media including magazines such as Business Week as well as the financial ratings company Standard \& Poors. Random House is owned by Bertelsmann, a privately owned German company with interests in music and newspapers as well as publishing. Macmillan, a division of the privately owned German Holtzbrinck group, is part of a group that includes Nature, scientific publishers such as Worth and W.H. Freeman, as well as newspapers.

I mentioned that the top 20 publishers in Australia account for about $77 \%$ of the sales of all books. So who are these publishers? (note 28)

Table 1: Top 20 publishers in Australia

\begin{tabular}{|c|c|}
\hline \multirow{2}{*}{$\begin{array}{l}\text { 1-2 Pearson } \\
\text { Australia }\end{array}$} & Pearson Education and Penguin \\
\hline & $\begin{array}{l}\text { Owned by Pearson PLC, London (also own } \\
\text { the Financial Times) }\end{array}$ \\
\hline & Educational/Trade \\
\hline \multirow[t]{3}{*}{$\begin{array}{l}\text { 3-6 Reed } \\
\text { International } \\
\text { Books Australia }\end{array}$} & $\begin{array}{l}\text { Harcourt Education, LexisNexis, Elsevier and } \\
\text { Reed Business Publ }\end{array}$ \\
\hline & $\begin{array}{l}\text { Owned by Reed Elsevier, London and } \\
\text { Amsterdam }\end{array}$ \\
\hline & Professional/Educational/Trade \\
\hline \multirow[t]{3}{*}{ 7-8 Thomson } & $\begin{array}{l}\text { Thomson Legal and Regulatory - Law Book } \\
\text { (the largest legal publisher) and Thomson } \\
\text { Education }\end{array}$ \\
\hline & Owned by Thomson, Canada \\
\hline & Professional/Educational \\
\hline \multirow[t]{2}{*}{$\begin{array}{l}9 \text { Macmillan/Pan } \\
\text { Macmillan }\end{array}$} & $\begin{array}{l}\text { Owned by Von Holtzbrinck Group (privately } \\
\text { held company) }\end{array}$ \\
\hline & Educational/Trade \\
\hline \multirow[t]{2}{*}{$\begin{array}{l}10 \text { Allen \& } \\
\text { Unwin }\end{array}$} & Privately owned in Australia \\
\hline & Educational/Trade \\
\hline \multirow[t]{3}{*}{$\begin{array}{l}11 \text { Hodder } \\
\text { Headline }\end{array}$} & Now known as Hachette Livre Australia \\
\hline & Owned by Hachette France \\
\hline & Trade \\
\hline \multirow[t]{2}{*}{$\begin{array}{l}12 \text { Random } \\
\text { House }\end{array}$} & Owned by the Bertelsmann, Berlin \\
\hline & Trade \\
\hline
\end{tabular}




\begin{tabular}{||l||l||}
\hline \hline 13 HarperCollins & Owned by News Corporation, New York \\
\hline \hline 14 McGraw-Hill & $\begin{array}{l}\text { Owned by the McGraw-Hill NY (also own } \\
\text { Standard \& Poors) }\end{array}$ \\
\hline \hline $\begin{array}{l}\text { 15 Scholastic } \\
\text { Australia }\end{array}$ & Oducational \\
\hline \hline \begin{tabular}{l} 
16 John Wiley \\
\hline \hline $\begin{array}{l}\text { 17 Reader's } \\
\text { Digest }\end{array}$
\end{tabular} & Owned by Scholastic, US \\
\hline \hline \begin{tabular}{l} 
Owned by Reader's Digest, US \\
\hline \hline $\begin{array}{l}18 \text { Simon \& } \\
\text { Schuster }\end{array}$
\end{tabular} & Owned by Viacom, US \\
\hline \hline \begin{tabular}{l} 
Trade/Direct \\
\hline $\begin{array}{l}\text { Harlequin/Mills } \\
\text { \& Boon }\end{array}$
\end{tabular} & Owned by Torstar, Canada \\
\hline \hline & Trade \\
\hline \hline
\end{tabular}

Other significant players who could bounce in and out of the top 20 include Cambridge University Press, Lonely Planet (John Singleton is a major shareholder), Murdoch Books (owned by Rupert Murdoch's nephew Matt Handbury; it publishes cookbooks and similar titles), and Hardie Grant (privately owned in Australia; recently started a fiction list). Australian Consolidated Press also publishes a good number of books.

The market segments further into areas of specialisation.

Table 2: Market segmentation

\begin{tabular}{|c|c|c|}
\hline \begin{tabular}{|l|} 
Consumer (trade) \\
publishers \\
(alphabetical order)
\end{tabular} & Educational publishers & Professional publishers \\
\hline $\begin{array}{l}\text { Allen \& Unwin (independent } \\
\text { Australian) }\end{array}$ & Blackwell (Blackwell/UK) & CCH (Kluwer/German) \\
\hline $\begin{array}{l}\text { Hachette Livre (formerly } \\
\text { Hodder Headline/French) }\end{array}$ & $\begin{array}{l}\text { Cambridge University Press } \\
\text { (CUP/UK) }\end{array}$ & $\begin{array}{l}\text { Elsevier (Reed } \\
\text { Elsevier/AngloDutch) }\end{array}$ \\
\hline $\begin{array}{l}\text { Hardie Grant (independent } \\
\text { Australian) }\end{array}$ & $\begin{array}{l}\text { Harcourt Education (Reed } \\
\text { Elsevier/AngloDutch) }\end{array}$ & $\begin{array}{l}\text { LexisNexis (Reed } \\
\text { Elsevier/AngloDutch) }\end{array}$ \\
\hline $\begin{array}{l}\text { Harlequin (romance, } \\
\text { Torstar/Canada) }\end{array}$ & John Wiley (John Wiley/US) & $\begin{array}{l}\text { Thomson Legal and } \\
\text { Regulatory (formerly } \\
\text { Lawbook) }\end{array}$ \\
\hline HarperCollins (News/US) & $\begin{array}{l}\text { McGraw-Hill (McGraw- } \\
\text { Hill/US }\end{array}$ & \\
\hline $\begin{array}{l}\text { Lonely Planet (travel } \\
\text { specialist, independent } \\
\text { Australian) }\end{array}$ & \begin{tabular}{|l} 
Macmillan (Von \\
Holtzbrinck/German)
\end{tabular} & \\
\hline $\begin{array}{l}\text { Murdoch Books (mostly } \\
\text { cookbooks and lifestyle } \\
\text { books, independent } \\
\text { Australian) }\end{array}$ & $\begin{array}{l}\text { Oxford University Press } \\
\text { (OUP/UK) }\end{array}$ & \\
\hline $\begin{array}{l}\text { Pan Macmillan (von } \\
\text { Holtzbrinck) }\end{array}$ & $\begin{array}{l}\text { Pascal/Blake (independent } \\
\text { Australian) }\end{array}$ & \\
\hline
\end{tabular}




\begin{tabular}{||l||l||l||} 
Penguin (Pearson/British) & $\begin{array}{l}\text { Pearson Education } \\
\text { (Pearson/UK) }\end{array}$ & \\
\hline $\begin{array}{l}\text { Random House } \\
\text { (Bertelsmann/German) }\end{array}$ & $\begin{array}{l}\text { Thomson Learning } \\
\text { (Thomson/Canada) }\end{array}$ & \\
\hline Scholastic (Scholastic/US) & & \\
\hline $\begin{array}{l}\text { Simon \& Schuster } \\
\text { (Viacom/US) }\end{array}$ & & \\
\hline \hline
\end{tabular}

\section{Australian Authorship in Peril}

There are some worrying trends in the sales of books, as indicated in the table below.

Table 3. Sales and profitability of Australian publishing over time

\begin{tabular}{||r|r||r||r|r||r||}
\hline Period & $\begin{array}{c}\text { Number } \\
\text { of books } \\
\text { sold (m) }\end{array}$ & $\begin{array}{c}\text { Sales } \\
\text { value } \\
\text { (m) }\end{array}$ & $\begin{array}{c}\text { Average } \\
\text { price }\end{array}$ & $\begin{array}{r}\text { Operating } \\
\text { profit (m) }\end{array}$ & $\begin{array}{c}\text { Sales of } \\
\text { Australian } \\
\text { books (m) }\end{array}$ \\
\hline $\begin{array}{c}1995- \\
96\end{array}$ & 130.6 & $\$ 950.0$ & $\$ 7.27$ & NA & $\$ 561.1(59 \%)$ \\
\hline $\begin{array}{c}1997- \\
98\end{array}$ & 111.5 & $\$ 1035.6$ & $\$ 9.29$ & NA & $\begin{array}{r}\$ 623.5 \\
(60.2 \%)\end{array}$ \\
\hline $\begin{array}{c}1999- \\
01\end{array}$ & 129.4 & $\$ 1270.4$ & $\$ 9.82$ & $\$ 106$ & $\begin{array}{r}\$ 756.1 \\
(59.5 \%)\end{array}$ \\
\hline $\begin{array}{c}2000- \\
01\end{array}$ & 104 & $\$ 1261$ & $\$ 12.13$ & $\$ 63$ & $\begin{array}{r}\$ 747.7 \\
(59.3 \%)\end{array}$ \\
\hline $\begin{array}{c}2001- \\
02\end{array}$ & 129.5 & $\$ 1340.8$ & $\$ 10.35$ & $\$ 60.6$ & $\begin{array}{r}\$ 853.8 \\
(63.6 \%)\end{array}$ \\
\hline $\begin{array}{c}2002- \\
03\end{array}$ & 114.4 & $\$ 1369.4$ & $\$ 11.97$ & $\$ 88.4$ & $\$ 877(64 \%)$ \\
\hline $\begin{array}{c}2003- \\
04\end{array}$ & 128.8 & $\$ 1353.3$ & $\$ 8.89$ & $\$ 152.1$ & $\$ 811.9(60 \%)$ \\
\hline \hline
\end{tabular}

Source: $A B S$

The number of books being sold isn't increasing by much. Sales of books declined by $19 \%$ after the introduction of the goods and sales tax (GST) in 2000 , but GST cannot be regarded as the only cause as sales also fluctuated downwards by 20 million, or $15 \%$, in 1997-98. They surged back in 2001-02, but operating profit for publishers continued to decline, particularly for the top 20, and sales again declined in 2002-03. The value of sales, however, has increased year by year, except in 2000-01 when GST was introduced, until 2003-04, when it declined again. The proportion of Australian books making up these sales increased to $64 \%$ in 2002-03, a proportion much the same for consumer books as education books (the figure is about 1\% lower for educational books), but the figure dropped in 2003-04 to $60 \%$.

Table 4. Sales of Australia-originated books by category

\begin{tabular}{||c||r||r|r|r||}
\hline Period & \multicolumn{1}{|c|}{ Fiction } & Nonfiction & Children's & Education \\
\hline $\begin{array}{c}2000- \\
01\end{array}$ & $\$ 78.7$ & $\$ 261.2$ & $\$ 45.3$ & $\$ 295.9$ \\
\hline $\begin{array}{c}2001- \\
02\end{array}$ & $\$ 125.2$ & $\$ 292.2$ & $\$ 40.9$ & $\$ 310.2$ \\
\hline $\begin{array}{c}2002- \\
03\end{array}$ & $\$ 118.5$ & $\$ 311.6$ & $\$ 42.9$ & $\$ 328.4$ \\
\hline \hline
\end{tabular}


In 2003-04, sales of educational books declined, and sales of Australian fiction plummeted (see Table 3 ). There are some in the publishing industry who look at these figures with alarm and argue that publishing is in decline, under threat from electronic competition from DVDs and computer games. But it should be remembered that the number of books published in Australia plummeted 20\% in 1981, with consequent loss of sales, and the market recovered, even under the threat of videos. Books have shown remarkable resilience, even as the level of readership appears to be decreasing. What is remarkable is that readership levels maintain a relatively high standing despite the increased demands on leisure time provided by electronic alternatives.

Even so, there is plenty to be concerned about regarding the publishing of books relevant to Australia's literary culture. Table 3 shows that the sale of Australian-originated books declined by $\$ 50$ million in 2003-04 after healthy increases in previous years. The industry has only been subject to this degree of analysis since 2000, and the ABS currently proposes to discontinue to survey the industry in such detail, so this snapshot, inconclusive as it is, may be the only information retrievable on the state of Australian-originated publishing. The Australian Publishers' Association, whose membership is dominated by large, overseas-owned corporations, interprets this information differently in the September 2005 ASA Update (note 29). The APA records 'the news is pretty good' and so it is for overseas-owned publishers. Profitability increased in 2003-04, a result of lower costs, even though sales dropped $\$ 18$ million on those in 2002-03 and the hardest hit part of the market was Australian-produced books. The publishing of Australian originated fiction publishing appears to have reached a peak of $\$ 125.2$ million in 2001-02 when the category outsold imported fiction ( $\$ 102.5$ million; Table 4) and is declining. Only \$73.1 million in sales of Australian fiction were achieved in 2003-04 compared to $\$ 116.6$ million for imported fiction. Mass-market paperbacks have the highest sales value compared to trade paperbacks and hardbacks. Because the unit price of mass-market paperbacks is much lower, however, the return to an author per copy is much less, assuming that all authors receive a royalty of $10 \%$ of recommended retail price. And as I mentioned earlier, the decline in sales of Australian-originated books is reflected in the fact that royalties and fees paid by publishers in 2003-04 declined $11 \%$ on the previous year.

Table 5: Comparison of income from sales of Australian and imported books

\begin{tabular}{||c|r|r|r|r|r||r||}
\hline Period & $\begin{array}{c}\text { Australian } \\
\text { Fiction } \\
\mathbf{( m )}\end{array}$ & $\begin{array}{c}\text { Imported } \\
\text { Fiction } \\
\mathbf{( m )}\end{array}$ & $\begin{array}{c}\text { Australian } \\
\text { Nonfiction } \\
\mathbf{( m )}\end{array}$ & $\begin{array}{c}\text { Imported } \\
\text { Nonfiction } \\
\mathbf{( m )}\end{array}$ & $\begin{array}{c}\text { Australian } \\
\text { Children's } \\
\mathbf{( m )}\end{array}$ & $\begin{array}{l}\text { Imported } \\
\text { Children's } \\
\mathbf{( m )}\end{array}$ \\
\hline $\begin{array}{c}2000- \\
01\end{array}$ & $\$ 78.7$ & $\$ 101.3$ & $\$ 261.2$ & $\$ 170.8$ & $\$ 45.3$ & $\$ 105.7$ \\
\hline $\begin{array}{c}2001- \\
02\end{array}$ & $\$ 125.2$ & $\$ 102.5$ & $\$ 292.2$ & $\$ 104.8$ & $\$ 40.9$ & $\$ 75.1$ \\
\hline $\begin{array}{c}2002- \\
03\end{array}$ & $\$ 118.5$ & $\$ 90.2$ & $\$ 311.6$ & $\$ 130.8$ & $\$ 42.9$ & $\$ 64.9$ \\
\hline $\begin{array}{c}2003- \\
04\end{array}$ & $\$ 73.1$ & $\$ 116.6$ & $\$ 310.1$ & $\$ 177.1$ & $\$ 54.2$ & $\$ 60.2$ \\
\hline
\end{tabular}


Sales of the nonfiction category, which covers cookbooks, self-help, and a diverse range of other subjects, is increasing. This is supported by data from Nielsen Bookscan which shows that nonfiction titles make up 53\% of the market for books while fiction makes up $28 \%$ and children's book make up 18\% (note 30). ABS data show non-fiction books, both Australian and imported, were worth $59 \%$ of general content sales in 2003-04. Sales of Australian originated children's books increased in 2003-04, but this market segment is still dominated by imported books. Of concern to all authors is the fact that the average selling price of Australian titles dropped from $\$ 11.36$ to $\$ 9.10$ (a 20\% decrease) between 2002-03 and 2003-04. For royalties calculated on the selling price, this represents a drop in income for authors. In contrast, the average salary of a publishing company employee rose $9 \%$ to $\$ 52,300$. Editors also had an award increase.

The market share of imported books is also a threat to Australian authors, and Table 5 shows the income from sales of Australian originated and imported books. The increase in non-fiction is not compensating for the drop in sales of fiction. Table 6 shows the number of new Australian titles being published.

Table 6: Number of new Australian titles published

\begin{tabular}{|c|c|c|c|c|c|}
\hline Period & $\begin{array}{l}\text { New titles } \\
\text { Australian } \\
\text { origin, non } \\
\text { educational }\end{array}$ & $\begin{array}{c}\text { New titles } \\
\text { Australian } \\
\text { origin, } \\
\text { educational }\end{array}$ & \begin{tabular}{|c|} 
Total \\
number of \\
Australian \\
origin \\
titles \\
\end{tabular} & $\begin{array}{c}\text { Titles not } \\
\text { originated } \\
\text { in } \\
\text { Australia }\end{array}$ & $\begin{array}{l}\text { Total new } \\
\text { Australian } \\
\text { titles }\end{array}$ \\
\hline $\begin{array}{c}2001- \\
02\end{array}$ & 3893 & 4165 & 8058 & 1020 & 9078 \\
\hline \begin{tabular}{|c|}
$2002-$ \\
03
\end{tabular} & 3694 & 4615 & 8310 & 243 & 8553 \\
\hline \begin{tabular}{|c|}
$2003-$ \\
04
\end{tabular} & 3724 & 4610 & 8334 & 268 & 8602 \\
\hline
\end{tabular}

Source: $A B S$

While the number of new titles in 2003-04 is marginally greater than the previous year, these titles appear on the face of the sales information to have lost market share.

\section{Trends in publishing}

There have always been trends in publishing. Genres result from the amalgamation of trends. Crime fiction, for example, evolved through the development of cheap paperbacks and a market demand for crime stories. Publishers today hope to pick trends by using data from sources such as BookScan, but the problem is that the data is retroactive, resulting from the manifestation of the trend. As Michael Webster, the Australian representative for Nielsen BookScan, says: 'Companies like BookScan can tell us what's selling; they can drill down to raw figures and reveal what's doing well, but it's still an art. Who knew that a kid's book about wizards would become a bestseller?' (note 31) But at the same time authors need to be conscious that the economics of publishing have not changed, even with new technology. Publishers still make most of the money generated by a book. Authors, if they are to be serious about their profession, need to know about the agreements they enter into. They may rely on an agent, but even the agreement with their agents should be fully understood. Authors 
also make their money out of licensing their intellectual property. At the very least, they should have some understanding of the basics of copyright, and be aware of their rights and the rights they licence. Recently, I was asked by a relatively prominent and reasonably experienced author whether or not she could print her book overseas, as her Australian publisher wasn't doing much to ensure foreign sales. This is not the sort of question you can answer over the phone with someone reading out clauses from a Memorandum of Agreement. You need to read the Agreement in full to understand what has been agreed. The author was surprised and exasperated when I wouldn't answer her query and asked instead for her to send me a copy of her publishing agreement. That agreement, with one of Australia's more prominent Australian publishers by the way, gave the publisher world rights to her book; so, no, she couldn't license an overseas printing. What she also didn't understand was that the published edition, that is the book in which her publisher had made an investment, was not hers to license even if she had not given the publisher world rights. Her manuscript and her words were her copyright, but another publisher could not print the Australian edition without agreement from the Australian publisher, regardless of whether or not she had licensed world rights or only territorial rights. This author didn't like the agreement she'd signed any more because it wouldn't let her do what she wanted to do but - and it's a big but - she'd signed the contract. She had entered into a legal agreement. She had obligations to her publisher. She had never sought any advice on this contract, she'd simply signed it; then, when she didn't like some of its provisions, she wanted me to bail her out. By that stage it was too late. However, with just a little bit of forethought, and a little research, this author would have been able to save herself the angst.

The ASA recommends Minimum Approved Contracts. Obviously these contracts reflect the best interests of the authors. Most signed contracts represent a negotiated position between this ASA ideal and the publisher's own interests and expectations. But where remuneration is concerned, authors need to place particular concern one royalty rates, rates for shared incomes such as CAL, and the manner in which a publisher will pay them. Reversion of rights is also important. For the consumer market, most of these concerns are addressesed reasonably well by publishers. In the educational market, however, the publishers involved offer contracts that have little resemblance to the ASA's Minimum Approved Contract. Educational publishers more often seek to have authors assign them copyright and generally also pay royalties based on net receipts (publishers' receipts) rather than on Recommended Retail Price (RRP). Educational publishers argue they need an assignment of copyright as they are likely to produce a number of editions of textbooks, and authors may not always be available for revisions. They also posit that they offer fairly standard discounts. There are differences in the terms of the contract offered in different educational sector sectors. This relates to the discount structures offered in those sectors The standard discount for higher education and TAFE texts is $33 \%$, and between $25 \%-40 \%$ for primary and secondary school books. A $7 \%$ royalty on net receipts paid on a school textbook is still an inadequate royalty. On the other hand a royalty of $15 \%$ on a tertiary textbook might equate to $10 \%$ of RRP. All educational authors receiving royalties based on net receipts may do marginally better when a publisher sells direct or at a lesser discount. Any author is this area need to do some work to understand how payments works, if he or she is to obtain suitable remuneration for their efforts.

I haven't touched on subsidiary rights such as film, adaptation, 
condensation or translation, registering for public lending right and educational lending right, seeking permission for use of copyrighted works and a range of other material, I'll just throw in the word defamation as a teaser, I consider should be part and parcel of any writer's kit-bag. Authors need to be professionally and creatively prepared. Both require research and hard work. Unfortunately, in discounting the importance of professional preparation in the education of young writers, we leave them unprepared for the real world of writing.

\section{Notes}

1. Fisher, Jeremy, 'By permission of G. M. Glaskin', Overland, no.169, Summer 2002, pp55-58. return to text

2. Van Langenberg, Carolyn, 'G. M. Glaskin, novelist and stockbroker', Overland, no.164, Spring 2001, pp74-78. return to text

3. Keneally, Thomas, Archival footage, Australian Author, December 2005, p6. return to text

4. This information gained from advertised positions in Weekly Book Newsletter, private conversations, and acquired knowledge. return to text

5. Throsby, David and Hollister, Virginia, Don't give up your day job: An economic study of professional artists in Australia, Australia Council for the Arts, Sydney, 2003, p45. return to text

6. Copyright Agency Ltd Annual Report 2004-05, p23. return to text

7. This and the following paragraphs, Public Lending Right Scheme Committee Annual Report 2003-2004, Department of Communications, Information technology and the Arts, Canberra, 2004. return to text

8. Hernandez, Greg, 'Hollywood box office horror continues,' Sydney Morning Herald, 28 June 2005, p18. return to text

9. Sources for this and preceding paragraph: 7.30 Report, ABC Television, 7 February, 2005; Australian Film Commission press release, 27 January, 2005; Motion Picture Distributors Association of Australia press release 21 January 2005. return to text

10. Sydney Morning Herald, 23-24 July 2005, p31, quoting Mediametrie and Sandra Levy, ABC. Percentages are derived from programming from September 2002 to April 2003. return to text

11. Adam Sherwin, The Times (London), 29 December 2004

http://www.timesonline.co.uk/article/0,2-1418108,00.html return to text

12. Source for this and preceding paragraphs: Australian record sales - 2004 full year results, http://www.aria.com.au/pages/AustralianRecordSales2004FullYearResults.htm (accessed July 2005). return to text

13. Garry Barker, 'Will video be killed by the rising star DVD?' The Age, 12 February 2004. return to text

14. Knox, Malcolm, The Monthly, May 2005. return to text

15. http://www.acnielsen.com.au/product.asp?ProductID=45 (accessed July 2005). return to text

16. ASA Newsletter, no. 5, July 2004, p3. return to text

17. Australian Bookseller and Publisher, July 2005, p13. return to text 
18. http://www.smh.com.au/handheld/articles/2005/06/24/1119321902741.html? oneclick=true return to text

19. Australian Bookseller and Publisher, July 2005, p13. return to text

20. Source for this and following sentences: RR Bowker data reported by Rachel Deahl in The Book Standard, 24 May 2005. return to text

21. Book Industry Study Group, Under the Radar: A breakthrough, in-depth study of the book industry's underreported segments and channels, New York, 2005. return to text

22. http://www.publishers.org/industry/index.cfm return to text

23. Book Industry Study Group data reported by Associated Press, 31 May 2005. return to text

24. United Kingdom: UK Book Industry in Statistics 2004, British Publishers' Association. return to text

25. The statistics have been released since 2000 under the heading 'Book Publishers, Australia'. They are available at www.abs.gov.au return to text

26. Figures from 1980s, Australian Encyclopaedia, 4th ed, vol 8, pp167-169. return to text

27. Australian Publishers' Association Bestsellers' Survey 2005. Data is collected from 1 April to 31 March. return to text

28. This list has been put together on the basis of a range of information available to the ASA, but it is open to challenge. return to text

29. Australian Publishers Association, ASA Update, September 2005, vol 5/2, p6. return to text

30. Janelle McCulloch, 'Read all about it', Sunday Life, 3 July 2005, p27. return to text

31. Janelle McCulloch, 'Read all about it', Sunday Life, 3 July 2005, p27. return to text

\section{References}

AC Nielsen (2001) A national survey of reading, buying and borrowing books. Sydney, Books Alive.

Australian Bureau of Statistics 2003, Reading habits, book buying and borrowing, Year Book Australia: Culture and recreation - Literature and print media, http://www.abs.gov.au/ausstats/abs@,nsf/0/452019547c64bc5eca256dea00053a28? OpenDocument

Derricourt, R. (2002) 'Scholarly publishing in Australia: the impact of the last decade', Journal of Scholarly Publishing 33, 4, (July).

Hurston, Zora Neale (1942) Dust Tracks on a Road. New York: J.P. Lippincott.

Lokan, J., L. Greenwood and J. Cresswell (2001) 15-up and counting, reading, writing, reasoning... How literate are Australia's students? Melbourne, ACER.

Medawar, Peter, B. (1964) 'The Act of Creation'. New Statesman (19 June).

Moore, Brian (1990) Sunday Times (15 April).

Trillin, Calvin (1978) 'Uncivil Liberties'. The Nation (24 June). 
Young Australians reading: From keen to reluctant readers (2001) Prepared by Woolcott Research for the Australian Centre for Youth Literature and the Audience and Market development Division of the Australia Council. Melbourne, ACYL.

Dr Jeremy Fisher is Executive Director of the Australian Society of Authors. This paper is based on a Plenary Address delivered on 25 November 2005 at Alchemy: Blending Research and Creativity, the Tenth Annual Conference of the Australian Association of Writing Programs, Curtin University of Technology, Perth, 25-27 November 2005.

Copyright (C) Australian Society of Authors 2005

\section{TEXT}

Vol 10 No 1 April 2006

http://www.griffith.edu.au/school/art/text/

Editors: Nigel Krauth \& Jen Webb

Text@griffith.edu.au 